Acta Universitatis Wratislaviensis • No 3772

Literatura i Kultura Popularna XXII, Wrocław 2016

DOI: $10.19195 / 0867-7441.22 .5$

\title{
Michał Mazurkiewicz
}

Uniwersytet Jana Kochanowskiego

\section{Motywy sportowe w polskiej sztuce międzywojennej — rekonesans}

Słowa kluczowe: sport, literatura, sztuka, kultura, Polska

Keywords: sport, literature, art, culture, Poland

„Sport jest doskonałym tematem dla sztuki. Omijanie go, jest omijaniem ważnego zjawiska w życiu. Dlaczego knajpa ma być świetnym tematem dla sztuki a boisko sportowe nie?"1

„O Sporcie, ty jesteś Piękno! Tyś architektem tej budowli ludzkiego ciała, które oddane niskim żądzom warte jest pogardy, a rzeźbione szlachetnym wysiłkiem staje się czarą wzniosłości. Żadne piękno nie może istnieć bez proporcji i równowagi, a tyś jest mistrzem niezrównanym obydwu, gdyż ty stwarzasz harmonię, ty nadajesz rytm ruchom, ty siłę zdobisz wdziękiem, a gibkość nasycasz mocą"2.

Sport jest istotnym zjawiskiem kulturowym przenikającym wiele dziedzin ludzkiej aktywności. Oddziałuje z ogromną siłą i jest trwale obecny w literaturze oraz sztuce, a twórców, szczególnie tych będących miłośnikami sportu, niemal od zawsze fascynował tkwiący w nim potencjał.

1 J. Parandowski, cyt. za: W. Lipoński, Sport: literatura, sztuka, Warszawa 1974, s. 7. Zob. też R. Cieślak, Match footballowy Kazimierza Wierzyńskiego na tle międzywojnia, [w:] Futbol w świecie sztuki, red. J. Ciechowicz, W. Moska, Gdańsk 2012, s. 171-178.

2 P. de Coubertin, Oda do sportu, http://www.olimpijski.pl/pl/130,oda-do-sportu.html, dostęp: 10.06.2016. 
Po odzyskaniu niepodległości w 1918 r. aktywność ruchowa cieszyła się ogromną popularnością w budzącym się do życia państwie polskim. W sporcie widziano szansę szeroko rozumianego odrodzenia narodu, doceniano jego rolę w przygotowaniu armii do walki w czasach wciąż realnego zagrożenia, dostrzegano jego pozytywny wpływ na młodzież. Wkroczył on również do świata sztuki.

Celem niniejszego artykułu jest ukazanie zainspirowanych sportem polskich artystów i pisarzy okresu międzywojnia, w tym także laureatów olimpijskich konkursów sztuki i literatury, jak np. poety Kazimierza Wierzyńskiego, malarza Władysława Skoczylasa czy rzeźbiarza Józefa Klukowskiego. Analizę ich motywacji i dorobku poprzedza wstęp ukazujący warunki, w jakich kształtował się sport w odrodzonej Polsce. Następnie zarysowane zostały początki polskiej sztuki czerpiącej natchnienie ze sportu i rozrywki — jej elementy znajdziemy np. u Leona Wyczółkowskiego czy Wojciecha Kossaka - a także narodziny literatury sportowej. Historia obecności sportu w sztuce i literaturze polskiej jest dosyć bogata. Analiza wymagała wniknięcia w historię polskiego sportu okresu międzywojennego, dokonania przeglądu dzieł zainteresowanych sportem artystów, jak również zapoznania się z licznymi publikacjami poświęconymi owemu zagadnieniu.

\section{Sport w odrodzonej Polsce — wstęp}

Sport rozwijał się na polskich ziemiach na długo przed I wojną światową. W drugiej połowie XIX w., najpierw na terytorium Galicji, powstały gniazda Towarzystwa Gimnastycznego „Sokół” (pierwszym był lwowski „Sokół”, powołany z inicjatywy lekarza Józefa Millereta i Ignacego Żegoty Krówczyńskiego ${ }^{3}$ ), zakładano też towarzystwa wioślarskie, łyżwiarskie i cyklistyczne. Co ważne, zrzeszenia sportowe zazwyczaj prowadziły równolegle działalność kulturalną i patriotyczną ${ }^{4}$. Jak zauważa Krzysztof Szujecki, „pierwsza wojna światowa znacząco

${ }^{3}$ Pierwszym prezesem Towarzystwa został Milleret, a wspierali go dziennikarz i redaktor wydawanej we Lwowie „Gazety Narodowej” Jan Dobrzański oraz lekarz Tadeusz Żuliński, późniejszy założyciel oficjalnego pisma Towarzystwa o nazwie „Przewodnik Gimnastyczny — Sokół”. Zob. W. Lipoński, Historia sportu, Warszawa 2012, s. 427. Na temat historii ruchu sokolego w Warszawie zob. J. Chełmecki, Wychowanie narodowe w działalności Towarzystwa Gimnastycznego „Sokót” w Warszawie w latach 1905-1939, [w:] Spoleczne i kulturowe wartości sportu, red. J. Kosiewicz, Warszawa 2007, s. 255-262. Statut warszawskiego „Sokoła” z 1906 r. — zob. Mazowiecka Biblioteka Cyfrowa, http://mbc.cyfrowemazowsze.pl/dlibra/doccontent?id=24966, dostęp: 15.05.2016.

${ }^{4}$ W przypadku „Sokoła”, organizacji dbającej o podtrzymywanie i rozwijanie świadomości narodowej, należy też pamiętać o paramilitarnym wymiarze strojów sportowych, składających się z czapki krakuski z piórem, spiętego pasem żakietu o kroju wojskowym z rabatami, spodni ze zwężanymi nogawkami wpuszczanymi w wysoko sznurowane buty, a także peleryny noszonej na lewym ramieniu. Stroje te ówcześnie traktowano jako substytut mundurów. 
zahamowała rozwój sportu w Polsce, ale go nie przekreśliła. Tworzono struktury organizacyjne naszego sportu $\mathrm{w}$ oparciu o zrzeszenia istniejące we wszystkich trzech zaborach"5.

Aktywność sportowa cieszyła się popularnością w odrodzonym po $1918 \mathrm{r}$. państwie, gdyż istniała w narodzie niezwykle intensywna potrzeba oddechu, odnowy, także fizycznej, po zaborach i wojnie. Sport postrzegano jako szansę odrodzenia biologicznego oraz gwaranta sprawnego żołnierza, potrzebnego wobec niepewnej sytuacji politycznej i zagrożenia ze strony byłych zaborców ${ }^{6}$. Konieczność rozwoju wychowania fizycznego w niepodległym państwie dostrzegał obrońca tradycyjnych gier i zabaw, profesor Uniwersytetu Lwowskiego, Eugeniusz Piasecki, który zorganizował Studium Wychowania Fizycznego przy Uniwersytecie Poznańskim. Studium to stało się zalążkiem pierwszej polskiej uczelni wychowania fizycznego (AWF Poznań). Piasecki był orędownikiem szerokiego upowszechnienia sportu. Widział dla niego miejsce w szkołach, miastach, wsiach, a nawet w szpitalach. Był też autorem ciekawych prac z zakresu wychowania fizycznego, np. Zabawy i gry ruchowe dzieci i młodzieży ${ }^{7}$.

Kultura fizyczna wraz z kulturą duchową stanowiły dla polskiego społeczeństwa źródło dumy i radości. W II Rzeczypospolitej sport uprawiali niemal wszyscy, bez względu na pochodzenie, wykształcenie czy wykonywany zawód. Dotyczy to wszystkich zamieszkujących ówczesną Polskę narodów. Istniały kluby żydowskie (np. Makabi Warszawa, 1915; Jutrzenka Kraków, 1910; Hasmonea Lwów, 19088), niemieckie (1. FC Katowice, 1905) czy ukraińskie (TS Ukraina Lwów, 1911; Podilla Tarnopol, 1908; Prołom Stanisławów, 192999). Przedstawiciele tych klubów częstokroć rywalizowali między sobą — na gruncie polskich lig — i z innymi drużynami, co przynosiło im, ale też całemu krajowi, rozliczne korzyści, przede wszystkim finansowe i społeczne ${ }^{10}$.

${ }^{5}$ K. Szujecki, Dwudziestolecie międzywojenne, t. 15. Sport, Warszawa 2013, s. 9.

6 W. Lipoński, Historia..., s. 542.

7 Książka Zabawy i gry ruchowe dzieci i młodzieży została wydana w 1916 r. Była to publikacja o charakterze dydaktycznym.

8 Odnośnie do klubów żydowskich w przedwojennej Polsce zob. np. publikację Muzeum Historycznego Miasta Krakowa: M.W. Belda et al., Machabeusze sportu: Sport żydowski w Krakowie, Kraków 2012.

${ }^{9}$ Ciekawy szkic poświęcony organizacjom sportowym zrzeszającym mniejszość ukraińską („Płast”), realizującym program wzorowany na angielskim skautingu, przedstawił Stanisław Zaborniak, Tradycje skautingu w działalności organizacji młodzieżowej „Płast” na ziemiach polskich w latach 1911-1939 w 100-lecie ruchu skautingowego gen. Roberta Baden-Powella, [w:] Spoleczne i kulturowe wartości sportu ..., s. 263-273.

10 Jak odnotowuje Robert Gawkowski: „Działacze różnych narodowościowo klubów czasami w tej różnorodności dostrzegali korzyść finansową — na mecze polskich drużyn z ukraińskimi, niemieckimi czy żydowskimi przychodziło więcej osób, niż na zwyczajny mecz. Kibice widzieli w tych pojedynkach aspekt rywalizacji międzynarodowej" - R. Gawkowski, Sport w II Rzeczpospolitej, Warszawa 2012, s. 73. Ponadto, co chyba najważniejsze, „Sport łagodził wzajemne animo- 
Z każdym rokiem liczba zarejestrowanych zrzeszeń i klubów sportowych, jak również samych sportowców, wyraźnie rosła. Podsumowuje to Ryszard Wroczyński: „W roku 1918 czynne uczestnictwo wyrażało się liczbą około 43000 osób na terenie całego kraju; liczba ta wzrosła do roku 1939 ponad dziesięciokrotnie, osiągając około 500000 osób"11. Kluby sportowe dbały nie tylko o sprawność cielesną, ale także o rozwój duchowy. Stąd właśnie tak częsta obecność w ówczesnych klubach sekcji kulturalno-oświatowych, bibliotek, a nawet chórów i orkiestr.

Ważną rolę przełomowego — z historycznych względów — roku 1921 podkreślał „Przegląd Sportowy” z 1928 r.:

Pierwsze dwa lata niepodległości sportowcy spędzili na szańcach obrony ojczyzny. Kogo jak kogo, ale ich wśród szeregów żołnierskich nigdy nie brakło i haracz krwi złożyli aż nadto obfity [...]. Zbliżająca się ze wschodu nawała bolszewicka kazała zapomnieć o sporcie, zamiast dysku chwycić karabin, kulę zastąpić granatem ręcznym, a oszczep — lancą ułańską. Toteż dopiero rok 1921-y nazwać można rokiem kładzenia fundamentów pod wielki gmach sportu polskiego ${ }^{12}$.

Warto odnotować, iż sport zdecydowanie zmieniał swój charakter — stopniowo kształtowała się ,era widza i spektaklu”13, również w Polsce. Na przykład w przedwojennej Warszawie niezwykle popularne były masowe imprezy sportowe: mecze piłkarskie, biegi uliczne, wyścigi kolarskie, spotkania bokserskie czy zapaśnicze (choćby w szalenie popularnym cyrku Braci Staniewskich przy ul. Ordynackiej). Inspiratorami aktywności fizycznej były Polskie Radio oraz redakcje gazet, m.in. „Kurier Warszawski”, „Przegląd Sportowy” czy „Stadion”. Jak podkreśla Barbara Pędraszewska, „każde tego typu wydarzenie odbywało się przy udziale licznie zgromadzonej publiczności" ${ }^{14}$. Widowiska sportowe w całym kraju — piłkarskie, lekkoatletyczne, hokejowe (warto wspomnieć Mistrzostwa Świata w hokeju w Krynicy w 1931 r.) i inne - szybko uformowały świat oddanych kibiców, do którego należało wielu luminarzy II Rzeczypospolitej. Robert Gawkowski relacjonuje, że „kibicami byli politycy (premier Julian Nowak, Bolesław Wieniawa-Długoszowski, na meczach futbolowych bywał Józef Piłsudski), aktorzy (Adolf Dymsza, Kazimierz Rudzki, Michał Znicz), profesorowie (Józef Weyssenhoff)" 15 . Na stadionach pojawiały się też przedwojenne celebrytki Zula Pogorzelska czy Stefania Górska. Dzięki prężnemu rynkowi prasowemu,

zje i pomagał pokonać uprzedzenia narodowościowe. Kto wie, czy w wielonarodowej Rzeczpospolitej nie był jedną z nielicznych płaszczyzn wzajemnego porozumienia” (ibidem).

11 R. Wroczyński, Powszechne dzieje wychowania fizycznego i sportu, Wrocław 1985, s. 345.

12 „Przegląd Sportowy” 17 lipca 1928, nr 51, s. 1.

13 B.G. Rader, American Sports. From the Age of Folk Games to the Age of Spectators, New Jersey 1983.

14 B. Pędraszewska, Społeczne uwarunkowania rozwoju aktywności fizycznej w przedwojennej stolicy, [w:] Spoleczne i kulturowe wartości sportu..., s. 274-281.

15 R. Gawkowski, op. cit., s. 49. Dla przykładu: Adolf Dymsza, oddany kibic Polonii Warszawa, grał w rezerwach warszawskiego klubu, a na meczach zasiadał w loży honorowej. Umiejętności sportowe i dusza kibica przydały mu się w rolach filmowych, m.in. w Sportowcu 
jak również za sprawą „szeptanej informacji”, społeczeństwo na bieżąco otrzymywało informacje na temat życia prywatnego elit, także tych „stadionowych”. Należy przy tej okazji wspomnieć o stałym upowszechnianiu się ubioru nieformalnego w postaci strojów sportowych (także u kobiet), co wiązało się z coraz większą aktywnością fizyczną Polaków, coraz modniejszym „zażywaniem kąpieli słonecznych i wodnych", jak również wychodzeniem w góry czy też bywaniem na imprezach sportowych. Tworzyło to swoisty kult witalności ${ }^{16}$.

Nie bez znaczenia był też rozwój polskiej sztuki filmowej i jej oddziaływanie na proces kształtowania się rodzimej kultury i obyczaju poprzez propagowanie określonych postaw. Tematyka sportowa pojawia się np. w wielkim hicie filmowym przedwojennej Polski Jadzia (reż. M. Krawicz, 1936), w którym rywalizują z sobą dwie firmy handlujące sprzętem sportowym. Jedną ze scen, rozgrywającą się nad rzeką, krytyk filmowy Miłosz Drewniak nazywa „swego rodzaju panoramą zachowań ówczesnych Polaków w sferze aktywności fizycznej"17. Ruch na świeżym powietrzu promowały też filmowe szlagiery, jak choćby Ach, jak przyjemnie Henryka Warsa (z filmu Zapomniana melodia z 1938 r.). Istotną obecność sportu w filmowym przedstawianiu form spędzania czasu wolnego odnotowuje także filmoznawca Wojciech Otto:

Wielkim powodzeniem cieszył się także sport, a poza tym — spacery na warszawskich skwerach, zabawy w wesołych miasteczkach oraz randki w popularnych kawiarniach, a wieczorami - nocne kluby i tzw. jaskinie hazardu. [...] Bohaterowie z ochotą odwiedzali iluzjony, rewie, teatry i kabarety (Jego wielka miłość [...] Krawicza, 1936; Ada, to nie wypada Konrada Toma), thumnie gromadzili się na wyścigach konnych, meczach hokejowych i zakopiańskich konkursach skoków narciarskich (Mocny człowiek Henryka Szaro, Sportowiec mimo woli $^{18}$ [...] Krawicza, Biały ślad Adama Krzeptowskiego $)^{19}$.

Na fali rosnącej popularności przyszły ogromne sukcesy polskich sportowców. Tak opisuje je autor książek poświęconych dziejom Warszawy Juliusz Kulesza:

Po latach niewoli sport nasz wchodził w dwudziestolecie z niskiego szczebla, ale prędko począł rosnąć w siłę. Zaczęło się od złotego medalu olimpijskiego Haliny Konopackiej (1928),

mimo woli (1939), gdzie wcielił się w hokeistę. Więcej na ten temat podaje Gawkowski w rozdziale Warszawskie elity na meczach, [w:] idem, Futbol dawnej Warszawy, Warszawa 2016.

16 Zob. A. Sieradzka, Moda w przedwojennej Polsce, Warszawa 2013, lub A. Legierska, Dżentelmeni i gorszycielki. Moda w przedwojennej Polsce, http://culture.pl/pl/artykul/dzentelmeni-i-gorszycielki-moda-w-przedwojennej-polsce (wpis z dnia 14 października 2014; dostęp: 25.06.2016).

17 M. Drewniak, Czarno na biatym — „Jadzia — po prostu Jadzia, ale jak to brzmi...”, http://film.org.pl/r/recenzje/czarno-na-bialym/czarno-na-bialym-jadzia-po-prostu-jadzia-ale-jak-to-brzmi-4-44191/ (wpis z dnia 15 listopada 2013; dostęp: 20.06.2016).

18 Film ten, z 1939 r., miał swoją premierę już podczas wojny.

19 W. Otto, Wielkomiejskie życie Drugiej Rzeczypospolitej w polskim filmie fabularnym okresu międzywojennego. Wstęp do tematu, „Images” XII, 2013, nr 21, s. 304-305. Osobnego namysłu wymagają również takie filmy, jak Placówka Ligi Morskiej i Rzecznej w Trokach, II Marsz szlakiem Batorego czy Letnie obozy sportowe młodzieży. Zob. A. Mikonis, Życie filmowe Wilna w okresie międzywojennym. Lata 1919-1939, „Kwartalnik Filmowy” 2003, nr 44, s. 211-228. 
a niebawem przyszły następne: złoto Stanisławy Walasiewiczówny i Janusza Kusocińskiego na igrzyskach w Los Angeles 1932. [...] Pod koniec lat trzydziestych wizytówką naszego sportu począł stawać się boks, z mistrzami i wicemistrzami Europy ${ }^{20}$.

\section{Rola Józefa Pilsudskiego}

Nie sposób tu nie wspomnieć wielkiego sojusznika sportu — Józefa Piłsudskiego. Marszałek, choć sam często powtarzał, iż nie rozumie sportu ${ }^{21}$, patronował wielu wydarzeniom sportowym, wręczał nagrody, dekorował czempionów, przyjął w Belwederze złotą medalistkę Igrzysk Olimpijskich w Amsterdamie Halinę Konopacką, dokonywał otwarcia obiektów sportowych. Był, ponadto, członkiem honorowym Polskiego Związku Szachowego, protektorem I Kongresu dla Spraw Wychowania Fizycznego i Sportu Kobiet w 1928 r. oraz II Kongresu Kultury Fizycznej Kobiet i Olimpiady Szachowej w Warszawie w 1934 r.

Marszałek uwielbiał grać w szachy, jeździł konno, polował, wzbraniał się jednak przed twierdzeniem, że uprawia sport. Sam swoich zajęć nie uważał za dyscypliny stricte sportowe, zwykł nawet mawiać, trochę przewrotnie, że „woli sportowanie, od sportu" 22 . Nie tolerował zawodowstwa, pogardliwie wypowiadał się też na temat ślepego bicia rekordów. Patrzył na sport głównie z wojskowego punktu widzenia.

Jak stwierdza Maciej Stańczyk:

Z jednej strony Piłsudski wspierał więc kulturę fizyczną, gdyż chciał „spotęgować sprawność bojową" służb mundurowych (wśród czynnych sportowców była liczna grupa żołnierzy i policjantów). Z drugiej strony dostrzegł w sporcie pretekst do głośniejszego zamanifestowania obecności niepodległej Polski na arenie międzynarodowej ${ }^{23}$.

Podczas plenarnego posiedzenia Rady Naukowej Wychowania Fizycznego w 1932 r. Marszałek podkreślał: „Sport jest olbrzymim elementem propagandowym, który wychowanie fizyczne wszędzie bardzo silnie uwydatnia"24.

Po przewrocie majowym Piłsudskiego, który mocno orędował za wprowadzaniem ćwiczeń fizycznych do szkół i rozwojem sportu, powołano z jego inicjatywy do życia Państwowy Urząd Wychowania Fizycznego i Przysposobienia

20 J. Kulesza, Zakazane gole. Futbol w okupowanej Warszawie, Warszawa 2014, s. 19.

21 O piłce nożnej mówił np.: ,czas wyznaczony meczom w tej grze, to wyduszanie sportu przez półtorej godziny, musi doprowadzić do zepsucia serca!". M. Stańczyk, Piłsudski od sportu wolat sportowanie, http://eurosport.onet.pl/pilsudski-od-sportu-wolal-sportowanie/x550x, dostęp: 5.03.2016. Garść wypowiedzi Marszałka na temat sportu z posiedzeń Rady Naukowej Wychowania Fizycznego zamieściła redakcja „Przeglądu Sportowego”. Zob. Myśli Marszałka Pitsudskiego o sporcie, „Przegląd Sportowy" 20 maja 1935, nr 48 (1056), s. 1.

22 M. Stańczyk, op. cit.

23 Ibidem.

24 Myśli Marszałka Piłsudskiego o sporcie..., s. 1. 
Wojskowego (1927) ${ }^{25}$, którego pracami w latach 1927-1939 kierowali kolejno: ppłk Juliusz Ulrych, płk Władysław Kiliński, gen. Józef Olszyna-Wilczyński i gen. Kazimierz Sawicki. Ustanowienie tej instytucji rozpoczęło proces przejmowania przez wojsko kluczowych funkcji w polskim ruchu sportowym. Urząd szczególnie dbał o patriotyczne wychowanie. W tym celu m.in. organizował zawody z okazji rocznic narodowych. Jego organem doradczym była wspomniana już Rada Naukowa Wychowania Fizycznego (RNWF), w skład której wchodzili nie tylko pracownicy naukowi, ale też przedstawiciele ministerstw. Zajmowała się ona problemami polskiej wsi. Organizacje kultury fizycznej pomagały w kształceniu sportowca na w pełni świadomego swych obowiązków obywatela II RP²6. A zatem nie bez powodu mieliśmy w swojej historii tylu sportowców patriotów, dla których II wojna światowa stała się nie tylko końcem kariery sportowej, ale i kresem życia, poświęconego w obronie ojczyzny.

\section{Sport w polskiej sztuce - początki}

Osiemnasto- i dziewiętnastowieczne malarstwo o tematyce sportowej, ze szczególnym zacięciem portretujące sporty konne, zaczęło powstawać w Wielkiej Brytanii (George Stubbs), następnie temat ten - podobnie jak inne rozrywki czasu wolnego - zaintrygował większość wybitnych impresjonistów francuskich (Édouard Manet, Claude Monet, Auguste Renoir) oraz niemieckich (Max Liebermann, Max Slevogt, Lovis Corinth).

Wyścigi konne, organizowane coraz częściej w pierwszej połowie XIX w., przyczyniły się do rozwoju malarstwa o tej tematyce w Polsce. Pierwsi polscy malarze scen konnych to Aleksander Orłowski i Piotr Michałowski. Ciekawy

25 Zob. P. Rozwadowski, Państwowy Urząd Wychowania Fizycznego i Przysposobienia Wojskowego 1927-1939, Warszawa 2000, s. 25. Statut PUWF i PW został uchwalony przez Radę Ministrów i wyszedł w postaci rozporządzenia RM. W sprawozdaniu z działalności PUWF i PW za rok 1928/1929 czytamy m.in.: „W programie uwzględnione jest zróżnicowanie metod pracy dla wsi i miasta, wychodząc z założenia, że miasto chwyta młodzież do różnych towarzystw gimnastycznych i sportowych, wieś zaś daje element przeważnie surowy. Dla młodzieży wiejskiej przeto kładziemy główny nacisk na gimnastykę, odpowiednie gry i zabawy sportowe oraz niektóre elementy lekkiej atletyki, aby wrodzonej sile rolnika dać konieczną giętkość. Pracę tę prowadzą obwodowi i powiatowi komendanci wychowania fizycznego i przysposobienia wojskowego, na wsi pierwsi i często jedyni pionierzy ruchu wychowania fizycznego, jego organizatorzy i instruktorzy". Trzecie plenarne posiedzenie Rady Naukowej Wychowania Fizycznego, Warszawa 1929, s. 9, cyt. za: E. Małolepszy, Polityka władz II Rzeczypospolitej wobec wychowania fizycznego i sportu na wsi, „Prace Naukowe Akademii im. J. Długosza w Częstochowie. Kultura Fizyczna” VI, Częstochowa 2005, s. 57-65.

${ }^{26}$ Dla przykładu, działalność Katolickich Stowarzyszeń Młodzieży Męskiej i Żeńskiej na polu kultury fizycznej opisuje Eligiusz Małolepszy, Kultura fizyczna w działalności Katolickich Stowarzyszeń Młodzieży Męskiej i Żeńskiej na wsi w II Rzeczypospolitej, [w:] Antropologia sportu, red. Z. Dziubiński, Warszawa 2002, s. 426-435. 
przykład stanowi twórczość malarza batalisty okresu romantyzmu Januarego Suchodolskiego (obraz Pierwsze wyścigi konne na Polu Mokotowskim w Warszawie z roku 1849), a także Stanisława Wolskiego, specjalizującego się w tematach historycznych i batalistycznych, ukazującego ponadto sceny z warszawskich parków oraz sceny polowań. Kolejni twórcy to Stanisław Lentz - malarz rysownik i karykaturzysta — przedstawiający codzienne epizody z życia mieszkańców Warszawy (np. Na torze wyścigowym, 1896), wreszcie Ksawery Pillati, działający w Warszawie głównie jako ilustrator czasopism (m.in. „Tygodnika Ilustrowanego") oraz książek, malarz licznych scen rodzajowych.

Chętnie przedstawiano też inne popularne w XIX w. sporty: łyżwiarstwo (wspomniany Pillati, Franciszek Reiss, Józef Wodziński, Antoni Kamieński) oraz wioślarstwo (Kamieński) ${ }^{27}$. Stanisław Rejchan, znany autor reportażowych rysunków, zarówno w kraju, jak i za granicą, ilustrator czasopism, m.in. w Paryżu, „uznawany za jednego z najwybitniejszych europejskich przedstawicieli tej dziedziny na przełomie lat 80 . i $90 . " 28$, modny portrecista wyższych sfer, bardzo chętnie ilustrował coraz bardziej popularny tenis (Tenis na korcie trawiastym z 1898 r.). Sport ten inspirował także Stanisława Dębickiego (impresjonistyczny Kort tenisowy z roku 1914). Znawca sztuki, Tadeusz Dobrowolski, tak opisuje jeden z jego obrazów:

Impresjonizm znowu wystąpił przejrzyście w olejno malowanym Korcie tenisowym z r. 1914, w którym udało się artyście przy użyciu jasnych zieleni, bieli i różów odtworzyć przymglenie atmosfery drgającej w upalnym świetle słonecznym ${ }^{29}$.

Pod koniec XIX i na początku XX w. tematykę sportowo-rozrywkową podejmowali też tacy mistrzowie polskiego malarstwa, jak Leon Wyczółkowski (Gra w krokieta, 1895) czy kontynuujący tradycję ojca Juliusza Wojciech Kossak (Polowanie par force u Józefa Potockiego w Antoninach, 1909, a także wiele innych dzieł o tematyce konnej). W II Rzeczypospolitej świat sztuki począł chłonąc inspiracje pochodzące ze świata sportu jeszcze intensywniej. Zostało to dostrzeżone również zagranicą. Przyjrzyjmy się zatem polskim laureatom olimpijskich konkursów sztuki i literatury.

\section{Olimpijskie konkursy sztuki i literatury}

Konkursy sztuki i literatury odbywały się w latach 1912-1948 równolegle ze sportowymi igrzyskami olimpijskimi. Pierwszą olimpiadą, w której mieli wziąć udział polscy artyści, były igrzyska w Paryżu (1924). Niestety, na skutek trudności finansowych, rząd polski nie zdecydował się asygnować funduszy na ten

27 W. Lipoński, Historia..., s. 495.

28 Wielka encyklopedia malarstwa polskiego, red. A. Górska, Kraków 2011, s. 540.

29 T. Dobrowolski, Sztuka Młodej Polski, Warszawa 1963, s. 281. 
cel. Środowisko artystyczne II Rzeczypospolitej zaznaczyło jednak swą obecność uczestnictwem w jury olimpijskiego konkursu — Olga Boznańska zasiadła w komisji malarstwa, Karol Szymanowski w komisji muzyki, Karol Stryjeński zaś w komisji architektury. Od 1928 r. polskie ekspozycje stanowiły ważny element kolejnych olimpiad.

Polscy medaliści olimpijskich konkursów sztuki i literatury to: w roku 1928 Kazimierz Wierzyński (złoto, poezja) i Władysław Skoczylas (brąz, grafika); w roku 1932 Józef Klukowski (złoto, rzeźba) oraz Janina Konarska (srebro, grafika); w roku 1936 Józef Klukowski (srebro, rzeźba), Jan Parandowski (brąz, proza) i Stanisław Ostoja-Chrostowski (brąz, grafika).

Dokonania wspomnianych laureatów prezentują się imponująco. Władysław Skoczylas (1883-1934) był malarzem, grafikiem, rzeźbiarzem i pedagogiem uważanym powszechnie za twórcę nowoczesnej szkoły polskiego drzeworytu. Prace jego „odznaczają się uproszczoną, rytmiczną kompozycją oraz świadomą prymitywizacją" ${ }^{30}$. Brązowy medal olimpijski otrzymał za cykl akwarel opartych o góralskie motywy myśliwskie: Łucznik II (stojący), Łucznik III (klęczacy), Jeleń świętego Huberta i Diana. Skoczylas nie tylko tworzył, ale też aktywnie zachęcał kolegów artystów do studiowania tematyki sportowej.

Janina Konarska (1900-1975) była malarką, graficzką, ilustratorką i rzeźbiarką, laureatką międzynarodowych konkursów grafiki. Jej drzeworyty cieszyły się wielką popularnością, przede wszystkim wizerunki świętych i prace o tematyce zwierzęcej. Została nagrodzona srebrnym medalem w olimpijskim konkursie sztuki i literatury w Los Angeles w 1932 r. za drzeworyt barwny Narciarze.

Stanisław Ostoja-Chrostowski (1897-1947) to polski rzeźbiarz, malarz i grafik, światowej sławy ilustrator specjalizujący się w drzeworycie. Zdobył brązowy medal na olimpijskim konkursie sztuki i literatury w Berlinie w 1936 r. za drzeworyt, a mówiąc dokładniej - drzeworytniczy projekt dyplomu Yacht Klubu Polskiego Korweta, przedstawiający szesnastowieczny okręt na pełnym morzu.

Józef Klukowski (1894-1945) był artystą, rzeźbiarzem i malarzem, a także oficerem Wojska Polskiego. Największe sukcesy odnosił jako twórca rzeźb — był dwukrotnym medalistą olimpijskim w konkursie sztuki i literatury. W 1932 w Los Angeles zdobył złoty medal za płaskorzeźbę Wieńczenie zawodnika. Cztery lata później w Berlinie zdobył srebro za dzieło Piłkarze. W malarstwie zajmował się również tematyką sportową ${ }^{31}$.

30 Słownik kultury polskiej, red. A. Górska, Kraków 2012, s. 569.

31 Wielka encyklopedia malarstwa polskiego..., s. 258. 
Sztuka o tematyce sportowej to także, rzecz jasna, grono twórców spoza kręgu artystów „olimpijskich”. W twórczości międzywojnia odnajdziemy szereg rozmaitych dyscyplin sportowych ${ }^{32}$. Należy w tym miejscu uwypuklić rolę prasy w popularyzacji tematyki sportowej w sztuce, co podkreśla historyk sportu Wojciech Lipoński:

W „usportowieniu” twórczości plastycznej sporą rolę odegrała szeroko zakrojona kampania prasowa, prowadzona w latach 1929-1936. Zainicjował ją Skoczylas [...] wywiadem, w którym ostro skrytykował artystów pomijających temat sportu. Wypowiedź ta zapoczątkowała dziesiątki, jeśli nie setki publikacji w podobnym duchu, od łagodnych prób przekonania obozu artystycznego o estetycznych walorach sportu, po imperatywne nawoływania w rodzaju: „Artyści! Do współpracy ze sportem!”’33.

Należy odnotować, iż w tym czasie prężnie rozwijał się reportaż sportowy, częstokroć zdobiony ilustracjami, ale wraz z upływem czasu zapotrzebowanie na rysunki do czasopism w zdecydowany sposób zmniejszyły reprodukcja mechaniczna i fotografia ${ }^{34}$.

\section{Sport w literaturze współczesnej — początki}

Pierwsze nowożytne powieści o tematyce sportowej, lub w dużej mierze uwzględniające sport, powstały w Anglii, co nie powinno dziwić, jeśli się uwzględni fakt, iż duża liczba dyscyplin sportowych narodziła się właśnie na Wyspach Brytyjskich. Były to: Szkolne lata Toma Browna Thomasa Hughesa ${ }^{35}$ (1857) oraz Profesja Cashela Byrona Georga Bernarda Shawa (1886). Już wcześniej jednak epizody sportowe pojawiały się w dziełach literatury angielskiej, np.

32 Bogaty nurt sportowy w polskim malarstwie, grafice (widoczny też w plakacie) i rzeźbie, szczególnie silny w latach 1929-1939, obejmował różne sporty, np. kolarstwo. Przykładem jest obraz Cykliści (1932) autorstwa braci bliźniaków Efraima i Menasze Seidenbeutlów (1903-1945), tworzących zazwyczaj swe dzieła wspólnie. Inni malarze zainteresowani tematyką sportową to np.: Wlastimil Hofman (Drużyna Wisły, 1927), Rafał Malczewski (Narciarze w Tatrach, 1927; Piłka nożna na przedmieściu, 1931), Felicjan Kowarski (Wioślarze, 1931), Wacław Borowski (Euczniczki, 1931), Tytus Czyżewski (Szermierz, 1932), Leon Chwistek (Mecz piłkarski, 1937) oraz Jadwiga Umińska (Boks, 1931). W tym ostatnim przypadku warto odnotować, iż „,recenzenci podkreślali w tym obrazie rzadką u artystów, szczególnie zaś u kobiet, umiejętność wniknięcia w istotę tego sportu" — W. Lipoński, Sport..., s. 305.

33 Ibidem, s. 304.

34 W. Lipoński, Historia..., s. 495.

35 Pierwsze wydanie: T. Hughes, Tom Brown's School Days, London 1857. Thomas Hughes był jednym z autorów (obok Charlesa Kingsleya) koncepcji i samego pojęcia „muskularnego chrześcijaństwa”, polegającego na sławieniu Boga zarówno poprzez rozwój duchowy, jak i cielesny. Zob. np. T. Ladd, J.A. Mathisen, Muscular Christianity: Evangelical Protestants and the Development of American Sport, Grand Rapids 1999. 
w Klubie Pickwicka Charlesa Dickensa. W dziewiętnastowiecznej Wielkiej Brytanii powstawały również liczne powieści i opowiadania poświęcone modnemu wówczas krykietowi, tworzące niejako odrębny gatunek.

W Europie kontynentalnej, w tym na ziemiach polskich, przede wszystkim na łamach prasy sportowej, uprawiano literaturę o tematyce sportowej na poziomie amatorskim. Należy jednak odnotować, iż wśród owych autorów amatorów zdarzali się literaci wyższej próby, jak np. Émile Zola czy Artur Oppman i Adam Asnyk. W Polsce w trend walki ze sportowym anglofilizmem wpisywała się doskonale sztuka Konstantego Gaszyńskiego Wyścigi konne w Warszawie (1858), w której autor nie oszczędza polskiej szlachty trwoniącej swój majątek na kupowanie angielskich wierzchowców i udział w wyścigach. Gaszyński z nostalgią wspomina czasy, gdy „nie szedł do Angielczyków z Polski okup złoty, za klacze skakające przez rowy i płoty" ${ }^{36}$. Wraz z rozwojem sportu w XX w. rosła liczba dzieł literackich, w których tematyka sportowa znajdowała poczesne miejsce. Dotyczy to także opowiadań (choćby Ferenike i Pejsidoros Lucjana Rydla, 1909) i poezji — jednym z wczesnych przykładów jest wiersz Dyskobol Kazimierza Przerwy-Tetmajera (1896).

\section{Kazimierz Wierzyński — liryczny adorator sportu}

„I pokażcie mi teraz — gdzie w jakich teatrach Milion widzów wystrzeli takim wielkim głosem"37.

Kazimierz Wierzyński (1894-1969), wybitny poeta i dziennikarz, jeden z założycieli czasopisma „Skamander”, debiutował w roku 1919 pełnym radości i entuzjazmu tomem wierszy Wiosna $i$ wino. Tom ten krytyk literacki Krzysztof Dybciak opisuje jako społecznie uznany najwartościowszy wkład rodzimej poezji w początkowy okres istnienia niepodległego państwa polskiego ${ }^{38}$. Podkreśla też ludyczne inspiracje wielu pierwszych utworów poety: „Mechanizmy zabawy pojawiają się na wszystkich poziomach tekstów pierwszych książek poetyckich Wierzyńskiego, choć nie wszędzie z jednakową częstotliwością"39. Można zatem stwierdzić, iż sport tkwił na tyle głęboko w psychice poety, iż wdzierał się niejako w jego twórczość. Predylekcje sportowe Wierzyńskiego przyczyniły się do tego, iż w latach 1926-1931 redagował on „Przegląd Sportowy”.

36 W. Lipoński, Historia..., s. 491-493.

37 K. Wierzyński, Match footballowy, [w:] idem, Laur olimpijski, Białystok 1985 (oryg. 1927), s. 30-31.

38 K. Dybciak, Gry i podróże poetyckie - Kazimierz Wierzyński, [w:] Poeci Dwudziestolecia Międzywojennego, t. 2, red. I. Maciejewska, Warszawa 1982, s. 447.

39 Ibidem, s. 455. 
Słynny tom nagrodzony złotem na olimpiadzie w 1928 r. - Laur olimpijski (1927) — „kontynuuje wątki strukturalne i filozoficzne wczesnego pisarstwa Wierzyńskiego"40. Jak stwierdza historyk literatury Lesław Eustachiewicz:

Tematyka sportowa Lauru olimpijskiego jest kontynuacją wierszy w stylu „Zielono mam w głowie i fiołki w niej kwitną...”. Mamy tu zatem do czynienia z poetycką pochwałą witalności, beztroski, upojenia życiem i naiwnym wdziękiem młodości ${ }^{41}$.

\section{Dybciak z kolei podkreśla:}

Zachwyt nad pięknem człowieczego wysiłku i ruchu, zmierzającego do przekroczenia narzuconych mu granic, znajduje wielokrotnie wyraz w tej poezji. Porównania do zjawisk przyrody (czasem techniki) wskazują, że dorównanie fenomenom przyrody jest miarą piękna i celem wysiłku ${ }^{42}$.

Laur olimpijski to nie tylko entuzjastyczny stosunek do sportu, nieskrępowany sensualizm, fascynacja ruchem i przyrodą. To także rozległa wiedza sportowa prezentowana przez autora. Opiewani są tu zwycięzcy i sławni mistrzowie przedwojennego sportu - Paavo Nurmi, Ricardo Zamora, Charles Paddock i inni. Podkreśla to Wojciech Lipoński:

Tomik poprzedzony drukiem kilku wierszy na łamach „Skamandra” uderza swobodą, z jaką Wierzyński porusza się po terenie sportu. $Z$ wierszy przeziera dziennikarskie znawstwo problemu. Autor nie staje z otwartymi ustami przed byle faktem sportowym, co się wówczas nader często przytrafiało intelektualistom dopiero odkrywającym tajniki sportu. $Z$ fachową nieomylnością dobiera elementy najistotniejsze. Tomik, z punktu widzenia sportowego jest niezwykle trafnym zestawieniem najważniejszych wydarzeń sportowych lat 1925-1927 $7^{43}$.

Teoretyczka literatury, Maria Dłuska, kładzie nacisk na rolę przedstawianych przez autora zwycięstw i porażek:

Złożony z zaledwie 15 wierszy Laur olimpijski był więcej niż pierwszym w naszej poezji arcydziełem opiewającym sport, a w nim piękno ciała ludzkiego. Istotą był tutaj romantyczny poryw. Zwycięstwo człowieka nad cielesnym bezwładem, nieuniknionym i, zdawałoby się nie do przezwyciężenia, oporem własnego ciała. Zwycięstwa miały wymiar nadludzki. Porażki [...] wstrząsają pełnym tragizmem też nadludzkiego wymiaru ${ }^{44}$.

Ponadto w tomie, w którym utwory częstokroć stylizowane są na antyk, widoczna jest doskonała zgodność między treścią a kształtem. Tematyka rządzącej się specyficznymi regułami walki oraz pochwała napięcia i wysiłku, opanowania i dążenia do zwycięstwa ,przedstawiane są za pomocą form precyzyjnych, ale nie pozbawionych lekkości i wdzięku. Struktura tych utworów świadczy o swo-

40 Ibidem, s. 462.

${ }^{41}$ L. Eustachiewicz, Dwudziestolecie 1919-1939, Warszawa 1990, s. 96.

42 K. Dybciak, op. cit., s. 462-463.

43 W. Lipoński, Sport..., s. 242.

44 M. Dłuska, Kazimierz Wierzyński, [w:] Obraz literatury polskiej XIX i XX wieku, seria 6, t. 2. Literatura polska w okresie międzywojennym, red. J. Kądziela et al., Kraków 1979, s. 327. 
bodnym i głębokim opanowaniu reguł gry poetyckiej"45. Warto tu odnotować, iż zjawisko poezji olimpijskiej można odnieść do utrwalonego kulturowo zjawiska poezji okolicznościowej — związanej tematycznie z ważnymi wydarzeniami życia publicznego, miejscami, jak również znanymi osobami. Jej początki sięgają starożytności, a okazje wyznaczały rytuały życia publicznego i prywatnego, w tym zawody sportowe. Dla przykładu, w starożytnej Grecji epinikiony (będące odmianą ody ku czci zwycięskich bohaterów, np. igrzysk olimpijskich) pisali Pindar i Bakchylides z Keos (VI/V w. p.n.e.).

Olimpijski sukces Wierzyńskiego, jak również Skoczylasa, spotkał się z entuzjastyczną reakcją ówczesnej prasy, np. „Tygodnika Ilustrowanego”, który triumfował: „Brawo Wierzyński! Brawo Skoczylas! Dzięki wam sztuka polska zamigotała nowym blaskiem w obliczu wszystkich narodów. Dzięki wam znowu uczczono biało-czerwoną flagę na międzynarodowej arenie!"46. Tom Laur olimpijski, doceniony niezwykle ważną olimpijską nagrodą, przyniósł Wierzyńskiemu popularność na całym świecie. Jego wiersze zostały przetłumaczone na główne języki europejskie oraz na nowogrecki, bułgarski, jidisz, japoński i łacinę. Tłumaczenie na język angielski zostało dokonane dopiero w 1957 r.

\section{Sport w literaturze II RP — inne przyklady}

Kontynuując nasze rozważania na temat poezji sportowej sprzed 1939 r., warto wspomnieć Józefa Gałuszkę, popularnego poetę międzywojnia, niestety, nieco zapomnianego po II wojnie światowej. Był on autorem wierszy o tematyce sportowej, drukowanych w różnych czasopismach. Należy też odnotować twórczość inspirowanych Wierzyńskim Jerzego S. Polaczka (tworzącego w Czechosłowacji) oraz poety i malarza Franciszka Janczyka. Także Tadeusz Peiper — czołowy przedstawiciel awangardy krakowskiej - dawał wyraz swej fascynacji sportem, a konkretnie futbolem, np. w wierszu Football (z tomiku Żywe linie, 1924).

$\mathrm{W}$ prozie na pierwszy plan zdecydowanie wybija się znawca i popularyzator kultury antycznej, autor Mitologii. Wierzeń i podań Greków i Rzymian (1924), Jan Parandowski. W 1932 r. na łamach „Tygodnika Ilustrowanego” pojawiła się lektura, który zapadła na trwałe w świadomości polskiego czytelnika jako symbol współczesnej literatury olimpijskiej - Dysk olimpijski. Powieść ta zdobyła brązowy medal na olimpijskim konkursie literatury w Berlinie (1936). Sukces zapewnił jej sam temat, a także jego spójność z ważnymi antycznymi wydarzeniami sportowymi. Dzieło to ukazuje bowiem wycinek rzeczywistości greckiej

${ }^{45}$ K. Dybciak, op. cit., s. 464.

46 P. Choynowski, Kronika, „Tygodnik Ilustrowany” 1928, nr 33, cyt. za: W. Lipoński, Historia..., s. 544. 
na kanwie wydarzeń historycznych, związanych z 76. olimpiadą grecką z $476 \mathrm{r}$. p.n.e. Do zalet Dysku olimpijskiego należą: emocjonalne zaangażowanie w losy bohaterów i w historyczne przemiany sportu oraz klarowny język dzieła.

Warto też odnotować istnienie literatury odcinkowej drukowanej w prasie, w tym także w prasie sportowej. Przykładem jest Wielka gra Aleksandra Reszki i Mariana Strzeleckiego (1937), powieść drukowana w odcinkach w „Przeglądzie Sportowym”. Jednym ze współpracowników Wierzyńskiego w tymże „Przeglądzie Sportowym” był Jerzy M. Rytard, poeta, prozaik i dziennikarz sportowy, autor opowiadań o tematyce sportowej ( $35^{\circ}$ w cieniu oraz $\mathrm{Mecz}$ - oba z tomu Bal jesienny z 1930 r.).

Także kobiety pisały o sporcie. Ogłoszony w 1931 przedolimpijski konkurs literacki wśród nagrodzonych prac przyniósł powieść pod tytułem Wiosna grecka, będącą debiutem pisarskim Hanny Malewskiej. Książka ta - poświęcona zamiłowaniom sportowym Platona - ujmuje nie tylko znawców starożytności; pisana jest barwnym językiem i posiada spore zalety artystyczne idące w parze z niezaprzeczalnymi walorami poznawczymi i dydaktycznymi. Prac literackich z Polski — nie doceniwszy ich wartości - nie wysłano jednak wówczas na igrzyska, co wywołało następnie falę krytyki i poczucie straconej szansy ${ }^{47}$.

\section{Zakończenie}

Wojciech Lipoński konstatuje: „oprócz sportu, chyba żadna inna dziedzina życia nie domaga się tak gromkim głosem własnej, tematycznie określonej literatury i sztuki”"48. Nie może zatem dziwić, że inspiracje sportowe odegrały (i wciąż odgrywają) ważką rolę, zarówno w polskiej, jak i w szeroko pojętej kulturze światowej. II Rzeczpospolita to pod wieloma względami fascynujący czas w dziejach Polski. Był to pełen wytężonej pracy okres tworzenia się kraju od podstaw, rozwoju, a nawet rozkwitu wielu dziedzin życia. Innymi słowy, można powiedzieć, iż mieliśmy wówczas do czynienia z procesem odnowy napędzanym przez prawdziwą eksplozję sił witalnych narodu. Sport był niewątpliwie istotnym segmentem nowo kształtującej się rzeczywistości. Państwo polskie tworzyło warunki rozwoju kultury fizycznej. Powstawała nowa infrastruktura sportowa. Zwiększanie nacisku na wychowanie fizyczne w szkole, ważna rola sportu w wojsku, rosnąca liczba związków, towarzystw i klubów - to wszystko sprawiało, że sport stawał się ważnym elementem tożsamości i dumy narodowej; coraz więcej Polaków zaczęło to wyraźnie dostrzegać. Za sprawą klubów i stowarzyszeń umacniał się też

47 Dla przykładu przywołajmy słowa historyka literatury Tadeusza Sinki, który na łamach „Kuriera Literacko-Naukowego” wyrażał swój żal: „Z pewnością otrzymałaby [...] światową nagrodę olimpijską, gdyby w jury zasiadali wysportowani platonicy” — „Kurier Literacko-Naukowy” 1933, nr 23.

48 W. Lipoński, Sport..., s. 317. 
lokalny patriotyzm. Coraz częstsze zawody sportowe na licznie wypełniających się arenach i pojawienie się pierwszych herosów sportu nie mogły pozostać bez wpływu na jego swoiste ,promieniowanie” poprzez wykraczanie poza stadion, co miało swe konsekwencje społeczne. Zmieniała się w sposób widoczny kultura czasu wolnego - ważnym jej elementem było uprawianie sportu i rekreacji (np. kajakarstwo i inne sporty wodne). Zauważyli to także — sami będący częstokroć entuzjastami tej czy innej dyscypliny — polscy literaci i artyści, o czym świadczy bogata i zróżnicowana spuścizna kulturalna II Rzeczypospolitej. Smutne koleje historii i dotkliwy cios zadany Polsce za sprawą II wojny światowej zakończyły pewną ważną epokę. Po 1945 r. znów przyszło odbudowywać kraj z ruin. Polski sport nie powstawał jednak z niebytu (odbywały się przecież podczas wojny liczne konspiracyjne rozgrywki). Powstawały nowe stadiony i nowa sztuka, także o tematyce sportowej. Co ciekawe, niejednokrotnie ukazywano w niej też wydarzenia sportowe okresu międzywojennego ${ }^{49}$.

\title{
Sports Motifs in Interwar Polish Art - a Reconnaissance
}

\author{
Summary
}

Sport is an important cultural phenomenon permeating many spheres of human activity. It has a great strength of influence and is constantly present in art and literature, also in Poland. Artists, especially the ones being lovers of sport, have always been fascinated with the potential existing in different kinds of games.

After regaining independence in 1918, physical activity enjoyed great popularity in the awakening Polish state. Sport was seen as a chance of broadly understood renaissance of the nation; in addition, its role in preparing the army to fight in the times of still real threats was appreciated. A positive influence of sport on youth was also seen. It also entered the world of art.

The aim of this paper is to present Polish artists inspired by sport, also including laureates of the Art Competitions at the Summer Olympics, like (for example) poet Kazimierz Wierzyński, painter Władysław Skoczylas or sculptor Józef Klukowski. The author analyses both their motivations and the artistic output. The examination is preceded by an introduction showing the beginnings of Polish art inspired by sport and entertainment, whose elements one will find for example in the case of Leon Wyczółkowski or Wojciech Kossak, as well as the beginnings of sports literature. The history of the presence of sport in Polish art and literature is quite rich. The research enquired exploration of the history of Polish antebellum sport, looking over the works of artists interested in sport, as well as familiarising oneself with numerous publications devoted to this phenomenon.

49 Interesująco wygląda konfrontacja realiów sportu w II Rzeczypospolitej z ich obrazem w filmie współczesnym. Warto tu przywołać scenę w cyrku w serialu Kariera Nikodema Dyzmy (reż. J. Rybkowski i M. Nowicki, 1980), stanowiącym ekranizację międzywojennej literatury, oraz sceny meczu piłkarskiego w filmie Vabank (reż. J. Machulski, 1981), kręcone na stadionie Olimpii Warszawa. Kwestia ta zasługuje na osobną, pogłębioną analizę. 